\title{
Optimization of process parameters for production of volatile fatty acid, biohydrogen and methane from anaerobic digestion
}

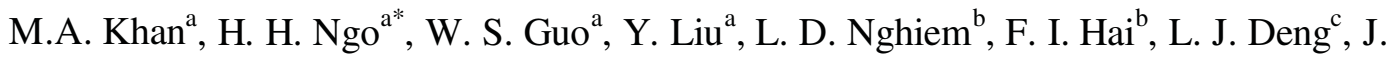 \\ $\mathrm{Wang}^{\mathrm{c}}, \mathrm{Y} \cdot \mathrm{Wu}^{\mathrm{c}}$
}

${ }^{a}$ Centre for Technology in Water and Wastewater, School of Civil and Environmental Engineering,

University of Technology Sydney, Sydney, NWS 2007, Australia

${ }^{b}$ Strategic Water Infrastructure Laboratory, School of Civil Mining and Environmental

Engineering, University of Wollongong, Wollongong, NSW 2522, Australia

${ }^{c}$ School of Environmental and Chemical Engineering, Tianjin Polytechnic University, Tianjin, 300387,

China

* Corresponding author: School of Civil and Environmental Engineering, University of Technology,

Sydney (UTS), P.O. Box 123, Broadway, NSW 2007, Australia. Tel.: +61 29514 2745; Fax: +61 29514

2633. E-mail address: ngohuuhao121@gmail.com

\section{Abstract}

The anaerobic digestion process has been primarily utilized for methane containing

biogas production over the past few years. However, the digestion process could also be optimized for producing volatile fatty acids (VFAs) and biohydrogen. This is the first review article that combines the optimization approaches for all three possible products from the anaerobic digestion. In this review study, the types and configurations of the bioreactor are discussed for each type of product. This is followed by a review on optimization of common process parameters (e.g. temperature, $\mathrm{pH}$, retention time and organic loading rate) separately for the production of VFA, biohydrogen and methane. This review also includes additional parameters, treatment methods or special additives that wield a significant and positive effect on production rate and these products' yield.

\section{Keywords}

Volatile Fatty Acid, biohydrogen, methane, biogas, anaerobic, retention time 


\section{Introduction}

Anaerobic digestion (AD) is considered to be an efficient, sustainable, and technically feasible way to treat waste sludge. It offers the benefits of mass reduction, pathogen removal and generation of methane (Bohutskyi et al., 2015; 2016; Shen et al., 2015). Methane production from AD has already been identified as a suitable process to produce bioenergy (Prajapati et al., 2013) but the poor biomass quality is one of the main reasons for low average useful energy production from anaerobic digestion (Pretel et al., 2015). Recent research studies have proved that the anaerobic process could be designed to produce volatile fatty acid, biohydrogen and/or bio-methane separately or simultaneously (Khan et al., 2016). Hydrogen is considered one of the cleanest energy sources and energy density per mass $\left(122 \mathrm{kJg}^{-1}\right)$ is 2.5 times compared to fossil fuels (Abdallah et al., 2016). VFAs are now proven to be a suitable precursor for the production of biopolymers (PHA) and other valuable products like biofuels, alcohols, aldehydes or ketones (Khan et al., 2016). Furthermore, the anaerobic digestion process could be coupled with another synthesis process to obtain products with higher value, e.g. pyrolysis to produce biochar (Monlau et al., 2016). Each of these production systems requires optimization of process parameters any specific product.

Unfortunately, there has been no literature that combines the optimization approaches for all of these potential products from the anaerobic digestion.

The aim of this paper is to identify the most common type of bioreactor arrangements that has produced positive and significant results. The optimum process conditions on these bioreactors have been discussed separately for VFAs, biohydrogen and methane production. Although there have been a number of critical process parameters that affect 
productivity, this discussion has been confined to the most common process variables, i.e. temperature, $\mathrm{pH}$, retention time (HRT and SRT) and the organic loading rate (OLR). Some specific treatment methods, additives, and other process parameters are beneficial, according to the most recent research findings. They are noted here at the end of the literature review for each product.

\section{Fundamentals of anaerobic digestion}

Anaerobic digestion is considered to be a complex process with a number of biochemical reactions where the reduction process is conducted by the microorganisms in anoxic conditions (Adekunle \& Okolie, 2015). The process involves four major stages: bacterial hydrolysis, acidogenesis, acetogenesis, and methanogenesis. The initial hydrolysis stage involves the enzyme-mediated conversion from suspended carbohydrates, proteins and fats into soluble amino acids, sugars and fatty acids. A number of hydrolytic microorganisms such as Bacterides, Clostridia, Micrococci, Selenomonas, and Streptococcus are the major drivers of the hydrolysis process (Adekunle \& Okolie, 2015).

During the stage of acidogenesis, the acidogenic bacteria converts the products from the initial hydrolysis stage into hydrogen, $\mathrm{CO}_{2}$, acetates and VFAs (Adekunle \& Okolie, 2015; Liu et al., 2012). The concentration of hydrogen formed as an intermediate product in this stage influences the type of final product produced during the fermentation process. Among the products from acidogenesis, the produced VFAs cannot be converted directly by the methanogens. Hence, the third stage involves the conversion of VFAs (acetic, propionic, and butyric acid) and alcohol into acetate, hydrogen gas and carbon dioxide (Wu et al., 2016). 
It should be mentioned that butyric and acetic acids have been reported to be the main precursors for methane production. From 65 to $95 \%$ methane is directly produced from acetic acid. The remaining major component, propionic acid remains unconverted as the degradation is thermodynamically less favourable compared to butyrate (Yu et al., 2016b). The final stage of methanogenesis mainly includes the function from acetotrophic and hydrogenotrophic methanogens. The acetotrophic group transform the acetate produced in acetogenesis into methane and carbon dioxide while the hydrogenotrophic methanogens convert hydrogen and carbon dioxide into methane (Andre et al., 2016).

Experiments have shown that the AD process is recognized as a useful mean of producing VFAs (Cysneiros et al., 2012), biohydrogen (Anzola-Rojas Mdel et al., 2016; Jariyaboon et al., 2015) and methane (Andre et al., 2016; Yang et al., 2015; Mao et al., 2015). Each of the production processes involves specific bioreactor arrangements and an optimum set point of process parameters.

\section{Optimizing volatile fatty acid production}

VFAs are produced in the initial hydrolysis on anaerobic digestion. A number of soluble organic acids are included in VFA but the major components are acetic acid, propionic acid, butyric acid, and valeric acid (Khan et al., 2016). So far, the completed research studies on the optimization of VFA production have been performed based on specific types of substrates (Scoma et al., 2016; Wang et al., 2014b; Yuan et al., 2011). The literature review below concentrates on the type of bioreactors and optimum process conditions for VFA production. 


\subsection{Types of Bioreactors for volatile fatty acid production}

The two most commonly used technologies for the production of VFAs are attached growth and suspended growth (Eddy, 1991). Both types of growth mechanisms have been implemented in different types of bioreactors. The packed bed bioreactor involves attachment of biomass on the packing material but is compromised by the problem of clogging. In contrast, the fluidized bed bioreactor eliminates the clogging problem where the biomass grows attached to small solid medium such as sand, which remains in suspension by the upward flowing motion of the fluid (Grady et al., 2011). In addition, the continuous stirred tank reactor (CSTR) is ideal to mix waste and microbes thoroughly in the presence of suspended solids and also offers complete mixing of waste and biomass. The most common reactor arrangement involves coupling a gravity settling clarifier coupled with the main bioreactor for separation and recycling the biomass to the bioreactor (Lee et al., 2014).

To produce volatile fatty acids, bioreactors could either be designed to produce VFA as the primary product (Wang et al., 2014b) or as a by-product (Peces et al., 2016). For production of VFA only, several bioreactor designs has provided promising results in terms of VFA production and separation such as: packed bed biofilm column reactor (Scoma et al., 2016), anaerobic leach bed reactors (Cysneiros et al., 2012), two-stage thermophilic anaerobic membrane bioreactor (Wijekoon et al., 2011), continuous stirred tank reactor (Bengtsson et al., 2008) and continuous flow fermentation reactors (Luo et al., 2014b).

\subsection{Optimum Conditions for extraction of volatile fatty acids}

The operating conditions for VFA production greatly vary according to bioreactor types, design, substrate composition and product spectrum. A suggestion has been 
proposed by Lee et al. (2014) between the mode of bioreactor operation and the rate of biomass decomposition. According to their recommendation, the batch or semicontinuous mode of operation is favorable over the continuous mode for UASB, packed and fluidized bed reactors.

Apart from the mode of operation, the optimum value of operating temperature, $\mathrm{pH}$, retention time and organic loading rate varies widely for different types of reactor systems and substrate conditions. Some specific actions such as sludge pre-treatment, hydraulic flushing helps the reactor acidification process, and finally helps to maximize VFA production from anaerobic digestion.

\subsubsection{Temperature}

Temperature has a significant effect on VFA production from anaerobic digestion. Yuan et al. (2011) studied the change in VFA concentration produced from waste activated sludge (WAS) in three different operating temperatures $\left(24.6,14\right.$ and $\left.4{ }^{\circ} \mathrm{C}\right)$. They concluded the highest VFA-COD production of $2154 \mathrm{mg} \mathrm{L}^{-1}$ at the operating temperature of $24.6^{\circ} \mathrm{C}$ in the shortest time of $6 \mathrm{~d}$, compared to the result of 2149 and $782 \mathrm{mg} \mathrm{L}^{-1}$ from 14 and $4{ }^{\circ} \mathrm{C}$, respectively. Additionally, the production rate and yield of VFA produced also improved when the temperature rose within the psychrophilic (4$\left.20{ }^{\circ} \mathrm{C}\right)$ and mesophilic $\left(20-50{ }^{\circ} \mathrm{C}\right)$ ranges (Yuan et al., 2011; Zhuo et al., 2012). This increment could be explained by the solubility of carbohydrates and proteins increasing at a high temperature and the rate of hydrolysis also rose as temperature increased (Liu et al., 2012).

The type of VFA produced has not been altered greatly when the temperature is changed during VFA production. Yuan et al. (2011) also showed that the composition 
of VFA produced in three different temperatures $\left(24.6,14\right.$ and $\left.4{ }^{\circ} \mathrm{C}\right)$ revealed no significant changes. This outcome included an increase in temperature (from $4{ }^{\circ} \mathrm{C}$ to $14{ }^{\circ} \mathrm{C}$ ) causing a reduction in acetate production from $55 \%$ to $43 \%$, yet the production of propionate and butyrate had an increase in percentage from $20 \%$ to $29 \%$ and $11 \%$ to $16 \%$, respectively.

Zhuo et al. (2012) studied the temperature effect on Ultrasonic pre-treated WAS fermentation at four different values: $10,20,37$, and $55^{\circ} \mathrm{C}$ under alkaline conditions. The results included a common trend of change in individual VFA production and no significant alteration in the composition of VFA produced. Increasing the temperature from $45-70^{\circ} \mathrm{C}$ does not create any positive impact on VFA production (Yu et al., 2013). In contrast, Zhuo et al. (2012) included that at $40^{\circ} \mathrm{C}$ there was a $40 \%$ decrease in total VFA production compared to that that of $37^{\circ} \mathrm{C}$.

It may be mentioned the microbial species present in different types of waste materials widely differ from each other, their growth rate in different temperature changes will be different. Consequently, identifying the change in growth rate of different types of microbial species could be a future research option for analyzing the impact of temperature in VFA production.

\subsection{2. $\mathrm{pH}$}

The amount of organic content being hydrolysed is the primary factor which is directly responsible for the amount of VFA produced. Along with the substrate composition, pH plays an important role in increasing the production rate and yield of VFA in anaerobic digestion. 
A comparative study was done to identify the accumulation of VFAs and microbial community structure of excess sludge (ES) at different pH values (Jie et al., 2014). Results found that at a $\mathrm{pH}$ level of 10, the accumulation of VFA reached its maximum limit. This finding was supported by another experiment (Wu et al., 2010) where alkaline fermentation of primary sludge for short-chain fatty acids (SCFAs) was studied. Results indicated that a $\mathrm{pH}$ range between 8.0-10.0 caused higher SCFAs accumulation when compared to $\mathrm{pH} 3.0-7.0$.

The $\mathrm{pH}$ range of extremely acidic (less than 3 ) or extremely alkaline conditions (above 12) are referred to as inhibitory conditions for the acidogens (Liu et al., 2012).

Although the optimal value of $\mathrm{pH}$ has been cited as high as 10 for the sludge hydrolysis mentioned above, this value may change to between 5.25 and 11 depending on the type of waste materials (Lee et al., 2014). For example, the anaerobic digestion of kitchen waste requires an optimum pH value equal to 7 (Wang et al., 2016) whereas the optimum $\mathrm{pH}$ condition for wastewater treatment ranges between 5.25 and 6.0 (Bengtsson et al., 2008).

In addition to the anaerobic digestion of excess sludge, the highest concentration of VFA is determined by the fermentation with inoculum and the HRT of the reactor. Based on these two additional factors the optimum $\mathrm{pH}$ values are changed. For example, Wang et al. (2014b) examined the effect of $\mathrm{pH}$ on different types of inoculum in eight different batch reactors over a fermentation period of 20 days. Results from this experiment indicated the maximum concentration and yield $(51.3 \mathrm{~g}-\mathrm{COD} / \mathrm{L}$ and a yield of $918 \mathrm{mg} / \mathrm{g} \mathrm{VSS}$ removal) for VFA at $\mathrm{pH}$ level 6.0. 
For production of VFA, the ratio of VFA to SCOD refers to the amount of soluble substances converted into VFAs (Jiang et al., 2013). Experiments also show that the pH range of 5.0 to 6.0 produced the highest value of VFA/SCOD ratio $(75 \%)$, regardless of the type of which inoculum was used while producing VFA from food waste. However, this experiment did not include the results for an extreme alkaline state $(\mathrm{pH}>10)$ (Wang et al., 2014b).

Although the composition of produced VFA primarily depends on the composition of the substrates, any changes in $\mathrm{pH}$ values can also control the type of VFA produced from acidogenic fermentation (Lee et al., 2014). Before the selective production of any specific type of volatile fatty acid, the optimum $\mathrm{pH}$ level needs to be determined.

\subsubsection{Retention Time}

In anaerobic digestion of waste materials the retention time of the waste and the microbial culture in bioreactor are important process parameters. Retention time includes hydraulic retention time (HRT) and solid retention time (SRT) which refer to the volume of the reactor and the allocated time for selected predominant microbes respectively. Experimental results have proved that that the production of VFA depends more on the hydraulic retention time compared to the temperature of a reactor (Kim et al., 2013).

A high value of HRT provides enough time for the acidogenic bacteria to reduce the waste into soluble derivatives and consequently it favors the VFA yield (Bengtsson et al., 2008). The hydraulic retention time for a system depends on the type and composition of the substrate. For instance, a HRT of 1.5 day was applied to VFA production and profile in anaerobic leach bed reactors digesting a high solids content 
substrate (Cysneiros et al., 2012) whereas 1.9-day HRT produced best performance in acidogenic anaerobic digestion of OFMSW (Romero Aguilar et al., 2013).

HRT values are only beneficial for VFA production up to a certain value, while prolonged HRT is responsible for the accumulation of VFA in the reactor. An experiment was performed to produce VFA from acidogenic fermentation of food (Lim et al., 2008). The results demonstrated that the production of VFA increased as the HRT increased from $96 \mathrm{~h}$ to $192 \mathrm{~h}$, but there was no further increase in VFA production once the HRT exceeded to $288 \mathrm{~h}$.

It has been identified that the growth rate of methanogens is slower compared to the growth rate of acidogens. As a result, a low SRT does not allow enough time for the methanogens to consume VFA and produce methane and carbon dioxide (Lee et al., 2014). In contrast, the acidogens require a minimum SRT to perform the hydrolysis of the substrates. A long SRT provides sufficient time for the methanogens and enables more biogas production, for instance, wastewater treatment using submerged anaerobic membrane bioreactors (SAnMBR) has a SRT range from 30 to 90 days (Huang et al., 2013).

\subsubsection{Organic loading rate}

The Organic loading rate (OLR) of a process is directly governed by the bioreactor arrangement and type and composition of substrates. So far, no direct relationship has been observed regarding the change in OLR and the yield or production rate of VFA.

However, the general trend of VFA production could be predicted with the change in OLR. For example, lactic acid fermentation from food waste with indigenous microbiota shows that the concentration of lactic acid initially increased with increasing 
the OLR. The lactic acid concentration rose from $29 \mathrm{~g} / \mathrm{L}$ to $37.6 \mathrm{~g} / \mathrm{L}$ when the OLR was increased from 14 to $18 \mathrm{~g}$-TS/L d (Tang et al., 2016). Yet, for the same experiment when the OLR was increased from $18 \mathrm{~g}$-TS/L d to $22 \mathrm{~g}$-TS/L $\mathrm{d}$ the acid production decreased sharply to $22 \mathrm{~g}-\mathrm{TS} / \mathrm{L} \mathrm{d}$. These results could be attributed to the contention that if the organic loading rate reaches beyond the optimum value the rate of hydrolysis is reduced.

A study of fermentation included two-phase olive oil mill solid residue over a range of different OLRs from 3.2 to $15.1 \mathrm{~g} \mathrm{COD} / \mathrm{L} / \mathrm{d}$. The result indicated that the maximum VFA concentration increased up to $12.9 \mathrm{~g} \mathrm{COD} / \mathrm{L} / \mathrm{d}$, and consequently a gradual decline was observed beyond 12.9 g COD/L/d (Rincon et al., 2008).

Similar results were observed during the production of VFA from food waste (Lim et al., 2008) using in once-a-day feeding and drawing-off bioreactor. An increase in VFA production was observed from the organic loading rate of $5 \mathrm{~g} / \mathrm{L} / \mathrm{d}$ to $13 \mathrm{~g} / \mathrm{L} / \mathrm{d}$, but beyond $13 \mathrm{~g} / \mathrm{L} / \mathrm{d}$ the reactor became unstable.

It can be summarized that production of VFA increases with the initial increase in OLR and the rate of production drops when OLR is increased further regardless the type and composition of the substrate. However, more research studies need to be done to characterize the range of optimum values in OLR along with the bioreactor design and type of substrates.

\subsubsection{Other Parameters}

In addition to the optimized process parameters, some specific additional measures can offer positive results for VFA yield and production rate. Actions such as hydraulic flush could increase the VFA production for a particular process. Experiments indicate 
that the hydraulic flush increased VS degradation and VFA production by $15 \%$ and $32 \%$ respectively, in buffered leach bed reactors that digested a high solids content substrate (Cysneiros et al., 2012).

Furthermore some chemical additives increase the production of VFA significantly; Table 1 summarizes the information concerning some common additives and their respective results in VFA production.

Table 1

\section{Optimizing biohydrogen Production}

In recent years the production of biohydrogen has attracted much research interest because it enables using waste materials compared to conventional electrolysis and thermo-catalytic reformation. An anaerobic system could be designed to produce biohydrogen as the major product (Abbasi \& Abbasi, 2011) or as a by-product with biodiesel or methane (Intanoo et al., 2016). Dark and photo-fermentation processes are the two major options for producing biohydrogen through the anaerobic method (Rittmann \& Herwig, 2012). The dark fermentation process involves the production of biohydrogen and VFA through the stage of acidogenesis by acidogenic bacteria such as Clostridium spp. Photo-fermentation process enables the biohydrogen production from

VFA with the presence of light, the predominant microbial community is photosynthetic bacteria such as Rhodobacter or Rhodopseudomonas spp. (Lee et al., 2012).

Unfortunately, the yield of biohydrogen from experiments has been significantly less than the expected theoretical yield; the difference is being that some of the raw materials are converted into by-products. During acidogenesis, butyrate and ethanol are 
produced that are termed as fermentation barriers to limit the hydrogen production. In connection, during anaerobic digestion, only one third of the electron potential is transferred to produce hydrogen, leaving the remaining two thirds being transferred to fermentation by-products (Abdallah et al., 2016).

\subsection{Types of bioreactors for biohydrogen production}

Different types of bioreactors have been employed for biohydrogen production including anaerobic down-flow structured bed reactor (Anzola-Rojas Mdel et al., 2016), upflow anaerobic sludge blanket reactor (UASBR) (Intanoo et al., 2014), continuous stirred tank reactor (Luo et al., 2010), continuously external circulating bioreactor (Liu et al., 2014) etc. Reactor models including a separate hydrogen fermenter using the conventional bioreactor design have shown promising results indicating a maximum yield and production rate of hydrogen; $1.13 \mathrm{~mol} \mathrm{H}_{2} / \mathrm{mol}$ glucose and $0.24 \mathrm{~mol} \mathrm{H}_{2} / \mathrm{L}$-d, respectively (Bakonyi et al., 2015). The configuration of the hydrogen fermenter along with subsequent downstream processing (biohydrogen recovery and purification) are two key factors that define the efficiency of a bioreactor producing biohydrogen (Kumar et al., 2015).

Bioreactors with two-stage assembly operations enable the simultaneous production of biohydrogen and methane. The particular advantage here is the ability to separate operating conditions (temperature, $\mathrm{pH}$ or retention time) being applied specifically to the microbes on each stage (Intanoo et al., 2016; Intanoo et al., 2014; Jariyaboon et al., 2015). However, the major drawback of two-stage arrangement is initial installation cost for reactor vessel and membrane module exceeds that for the single stage arrangement (Khan et al., 2016). Therefore, the cumulative product revenue is 
comparable to the additional costs involved in initial installation and operations such as controlling temperature, $\mathrm{pH}$ and membrane fouling.

\subsection{Optimum conditions for production of biohydrogen}

Although the type and organic content in the substrates are the major factors that control the production of biohydrogen, several process parameters are related to the production of biohydrogen. These include temperature, $\mathrm{pH}$, substrate composition, retention time, loading rate etc. (Bakonyi et al., 2015; Bakonyi et al., 2014). The following section details the effects of temperature, $\mathrm{pH}$, retention time and organic loading rate for production rate and yield of biohydrogen.

\subsubsection{Temperature}

Not many studies have compared the productivity of biohydrogen when using thermophilic, mesophilic and psychrophilic processes. Results for research data show that the overall production of biohydrogen did increase during thermophilic operation compared to the mesophilic strategy (Jariyaboon et al., 2015). The findings included a faster acclimatization rate of thermophilic inoculum compared to the mesophilic inoculum. Another analysis considered hydrogen production using two-stage induced bed reactors (IBR) from dairy waste processing (Zhong et al., 2015). The results indicated a value of $131.5 \mathrm{ml} \mathrm{H}_{2} / \mathrm{g}-\mathrm{COD}$ removed at $60{ }^{\circ} \mathrm{C}$ compared to $116.5 \mathrm{ml} \mathrm{H}_{2} / \mathrm{g}$ COD removed at $40^{\circ} \mathrm{C}$.

In the thermophilic scenario (temperature $55^{\circ} \mathrm{C}$ ) research was carried out for simultaneous production of biohydrogen and methane using a two-stage upflow anaerobic sludge blanket reactor (UASB) (Intanoo et al., 2014). Results were the maximum hydrogen production rate and highest $\mathrm{H}_{2}$ yield equal to $2.2 \mathrm{~L} / \mathrm{d}$ and $80.25 \mathrm{ml}$ 
$\mathrm{H}_{2} / \mathrm{g}$, respectively, during a COD loading rate of $90 \mathrm{~kg} / \mathrm{m}^{3} \mathrm{~d}$. In contrast, another study (Limwattanalert, 2011) documented the maximum amount of hydrogen produced in terms of maximum yield being $114.5 \mathrm{ml} \mathrm{H}_{2} / \mathrm{g}$ COD removed in the mesophilic context $\left(37^{\circ} \mathrm{C}\right)$.

The results obtained from these experiments confirm the veracity of two concepts. Firstly, in the thermophilic scenario, there is an improved solubility of the polymeric components such as lignocelluloses present in the substrates. Secondly, increasing the temperature, in turn, increases the activities of the enzymes (Zhong et al., 2015).

Another important aspect of biohydrogen production is the inhibition of methanogenic activities. To increase the biohydrogen production the population of hydrogenproducing bacteria should be increased and at the same time, repressing hydrogenconsuming bacteria such as methanogens. Two common methods for repressing the methanogens are heat shock and load shock treatment. For heat shock treatment, the sludge is treated at $100{ }^{\circ} \mathrm{C}$ for $30 \mathrm{~min}$ in an autoclave prior to use in cultivation (Jariyaboon et al., 2015). Research findings indicated that in the thermophilic state, the inhibition of methanogen is higher compared to the mesophilic one $\left(40^{\circ} \mathrm{C}\right)$ (Zhong et al., 2015).

The research findings do not provide any generalized temperature range that would be particularly beneficial for biohydrogen production. To identify the optimum temperature for any process, faster acclimatization of the inoculum and inhibition of the methanogenic activities should be considered under the optimum loading rate. 


\subsection{2. $\mathrm{pH}$}

For biohydrogen production, the growth rate microorganisms and dynamics of fermentation largely depend on the initial $\mathrm{pH}$ of the bioreactor. A change in $\mathrm{pH}$ triggers a microbial shift that eventually defines the metabolic pathway of the microorganisms. A variation of the hydrogen ion concentration causes a change in $\mathrm{pH}$ that eventually leads to the variation of discharges detected by the redox potential. Research has shown that activities of the fermentation products largely rely on the $\mathrm{pH}$ and it is an important ecological factor for hydrogen producing bacteria (Ruggeri \& Tommasi, 2015).

Although the optimum value of $\mathrm{pH}$ in a bioreactor varies according to the substrates' composition, research findings have indicated a favorable range that is common for all biohydrogen production processes through anaerobic digestion. Results from one experiment indicated the initial increase of $\mathrm{pH}$ in the acidic range favored biohydrogen production. This particular study concluded a $\mathrm{pH}$ value of 6.9 for maximum yield of hydrogen and a value of 7.2 for maximum average production rate for biohydrogen (Wang \& Wan, 2011).

Another experiment involved the production of biohydrogen in batch reactor using an initial concentration of $6000 \mathrm{mg} / \mathrm{L}$ glucose as a substrate (Liu et al., 2011). Their findings showed a $\mathrm{pH}$ value equal to 4 could discourage microbial growth. In addition, they reported that at $\mathrm{pH} 7.0$ the hydrogenase activity was low, which finally resulted in a low biohydrogen yield (ranged from $0.12-0.64 \mathrm{mmol} / \mathrm{mmol}$ glucose). They concluded that $\mathrm{pH}$ values from 5.5 to 6.8 are the most favorable for biohydrogen production.

Ruggeri \& Tommasi et al. (2015) performed a research study aiming to produce biohydrogen from noodle manufacturing wastewater. By analyzing Clostridium 
butyricum CGS5, the results included a $\mathrm{pH}$ value of 5.5 for maximum hydrogen production where a $\mathrm{pH}$ of 4.5 could have inhibitory effects.

Controlling the $\mathrm{pH}$ in a lab scale experiment may not reflect the real costs when the experiment is conducted in an industry context. However, the type of waste material and bioreactor type should be defined for more precise tuning of $\mathrm{pH}$ value in an anaerobic process.

\subsubsection{Retention time}

For biohydrogen production, hydraulic and solid retention time are critical design and operating parameters, since the reaction time between the microbial species and substrate removal efficiency both depend on HRT and SRT. Improving the production of biohydrogen implies the inhibition of bioactivity of hydrogen-consuming bacteria (both homoacetogens and hydrogenotrophic methanogens). Various studies' results contend that low HRT inhibits the activities of methanogens (Romero Aguilar et al., 2013). In addition, if the HRT is too short there is the potential of biomass washout from the system.

According to the experiment undertaken by Kumar et al. (2016), HRT values between 3 to 6 hours are favorable for the maximum biohydrogen production rate $\left(25.9 \mathrm{~L} \mathrm{H}_{2} / \mathrm{L}-\mathrm{d}\right)$ and yield (2.21 $\mathrm{mol} \mathrm{H}_{2} / \mathrm{mol}$ galactose), respectively at an OLR of $120 \mathrm{~g} / \mathrm{L}-\mathrm{d}$ with a high rate of continuous stirring in a tank reactor. Furthermore, a reduction of HRT from 2 hours reduced the production of biohydrogen indicating a biomass washout from the system.

Research studies were done to observe the specific hydrogen production (SHP) from a mixed substrate having a mixture ratio of 80:20 from municipal solid waste and food 
waste in a dry thermophilic anaerobic co-digestion $\left(55^{\circ} \mathrm{C}\right.$ and $20 \%$ solid content $)$ (Angeriz-Campoy et al., 2015). The applied SRT for the experiment ranged from 6.6 to 1.9 days and results indicated a decrease in SRT actually increased the production of hydrogen. The maximum rate of biohydrogen production in this experiment was 2.51 $\mathrm{L} \mathrm{H}_{2} / \mathrm{L}$ reactor day, and SHP was $38.1 \mathrm{~mL} \mathrm{H}_{2} / \mathrm{g} \mathrm{VS}$ added at an SRT of 1.9 days.

The findings are supported by another experiment aiming to produce biohydrogen from the fermentation of different galactose-glucose compositions (Kumar et al., 2014). At HRT 6 and 18 hours, the maximum hydrogen production rate and maximum hydrogen yield of $4.49 \mathrm{~L} / \mathrm{L} / \mathrm{d}$ and $1.62 \mathrm{~mol} / \mathrm{mol}$ glucose were attained. For the galactose, HRTs of 12 and $24 \mathrm{~h}$ produced a maximum production rate and yield valued at $2.35 \mathrm{~L} / \mathrm{L} / \mathrm{d}$ and $1.00 \mathrm{~mol} / \mathrm{mol}$ galactose, respectively.

It can be summarized that longer SRT and shorter HRT improve the efficiency of biohydrogen production. This outcome favors the population of active biohydrogen producers and consequently results in a high substrate conversion rate and a high percentage of yield (Jung et al., 2011).

\subsubsection{Organic loading rate}

The nutrient content comprising carbon sources are converted into molecular hydrogen gas during the anaerobic digestion process. For this reason, the organic loading rate needs to be optimized according to bioreactor design giving consideration to the maximum amount of produced biohydrogen. Results from research studies that have been already performed could be utilized to get a general connection between biohydrogen production and organic loading rate. 
It has been observed that the initial increase in the loading rate aids the production of biohydrogen (Zhang et al., 2013). The results include an initial increase in the organic loading rate from 4 to $22 \mathrm{~g} \mathrm{COD/L-d} \mathrm{has} \mathrm{a} \mathrm{positive} \mathrm{effect} \mathrm{on} \mathrm{biohydrogen} \mathrm{production.}$ This is in terms of production rate of $0.196 \mathrm{~mol} \mathrm{~d}^{-1} \mathrm{~L}^{-1}$, and subsequently, the biohydrogen production rate fell down to $0.160 \mathrm{~mol} \mathrm{~d}^{-1} \mathrm{~L}^{-1}$ when the organic loading rate increased from 22 to $30 \mathrm{~g} \mathrm{COD/L-d.}$

The maximum microbiological uptake for a certain bioreactor arrangement depends on whether the solid retention time is enough to enable the microorganisms to degrade the organic content efficiently. An experiment was undertaken in up-flow anaerobic packed bed reactors (APBR) with sugarcane vinasse indicated the optimum value of OLR equal to $84.2 \mathrm{~kg}-\mathrm{COD} \mathrm{m}^{-3} \mathrm{~d}^{-1}$. The mentioned OLR was able to produce the results of 1117.2 $\mathrm{mL}-\mathrm{H}_{2} \mathrm{~d}^{-1} \mathrm{~L}^{-1}$ reactor and $2.4 \mathrm{~mol}-\mathrm{H}_{2} \mathrm{~mol}^{-1}$ total carbohydrates as biohydrogen production rate and yield, respectively.

HRT and OLR are closely related to each other and defining a specific value for either one actually depends on both. The influence of OLRs and HRTs on hydrogen production was observed using a high salinity substrate by halophilic hydrogenproducing bacterium (HHPB) (Zhang et al., 2013). The maximum biohydrogen yield was $1.1 \mathrm{~mol}-\mathrm{H}_{2} / \mathrm{mol}$-glucose with optimum OLR of 20 g-glucose/L/day (range studied 10-60 g-glucose/L-reactor/day) and HRT of 12 h (range studied 24-6 h).

Kim et al (2012) studied the bio-hydrogen production from lactate-type fermentation at different OLRs (10, 15, 20 and $40 \mathrm{~g} / \mathrm{L} /$ day $)$ and HRTs (6, 12 and $24 \mathrm{~h})$. At an OLR of $40 \mathrm{~g} / \mathrm{L} /$ day, the optimum HRT was identified as $12 \mathrm{~h}$ for continuous biohydrogen production (Kim et al., 2012). The results implied low of yield biohydrogen if the HRT 
was decreased or increased from $12 \mathrm{~h}$ indicating the scenario of biomass washout or more biohydrogen consumption by methanogens respectively. Table 2 summarizes the effects of OLR and HRT on biohydrogen production using different types of substrates.

Table 2

\subsubsection{Other Parameters}

Very few experiments have investigated the positive effect on adding chemical additives and other relevant unit operations to increase the production of biohydrogen. Some specific treatment processes like recycling the substrates have shown promising results. Heat pre-treatment of inoculum can lead to positive results concerning the biohydrogen production rate. Luo et al., (2010) showed that hydrogen yield increased from about $14 \mathrm{ml} \mathrm{H}_{2} / \mathrm{gVS}$ in a mesophilic context to $69.6 \mathrm{ml} \mathrm{H}_{2} / \mathrm{gVS}$ under thermophilic conditions.

Addition of 2.8\% Tween $80 ®$ (T80) and $1.7 \mathrm{~g} / \mathrm{L}$ polyethylene glycol (PEG 6000®) during the treatment of organic fraction of municipal solid waste (OFMSW) has been proven to be beneficial for production of biohydrogen (Elsamadony et al., 2015). When these two additives were added the hydrogen yield increased to $116.7 \pm 5.2 \mathrm{ml}_{\mathrm{H} 2} / \mathrm{g}$ Carb.initial.

Fe content has also been proved to have positively influence the production of biohydrogen. The characterization of most $\mathrm{H}_{2}$-evolver enzymes occurs more easily with the presence of iron content in the active core/site. Experiments refer to an $\mathrm{H}_{2}$ production rate of $41.6 \mathrm{l} /$ day at $10.9 \mathrm{mg} \mathrm{FeSO} /$, and this is 1.59 times higher compared to $2.7 \mathrm{mg} \mathrm{FeSO}_{4} / \mathrm{l}$ (Lee et al., 2009). 


\section{Optimizing methane production}

Production of methane containing biogas through anaerobic digestion is the most common production method and has led to proven results through a number of experiments. Biogas has already been identified having the potential to replace fossil fuels in the future (Prajapati et al., 2013). Till now, most research approaches regarding process optimization are focused on the production of methane (Andre et al., 2016; Elsgaard et al., 2016; Zhong et al., 2015). During anaerobic digestion, methane is produced from the final stage of methanogenesis; this stage is referred to as the most vulnerable of all the phases and relies on the following: temperature, $\mathrm{pH}$, retention time, total ammonia nitrogen (TAN), and nutrient content of the bioreactor (Khan et al., 2016; Mao et al., 2015).

\subsection{Types of bioreactors for methane production}

Differently designed and configured bioreactors significantly affect the process of methane production, particularly in terms of retaining stability and efficiency. Several types of bioreactors have been utilized to study the production rate and yield of methane from different substrates. Among them, dry anaerobic digestion (Andre et al., 2016), field scale plug flow reactors (Arikan et al., 2015), anaerobic sludge blanket reactors (UASB) (Intanoo et al., 2016), continuously stirred tank reactor (CSTR) (Luo et al., 2010), induced bed reactors (IBR) (Zhong et al., 2015) and anaerobic membrane bioreactors (AnMBR) (Pretel et al., 2015) could be mentioned. Another bioreactor arrangement included a degassing membrane unit coupled with a UASB reactor. It improved the methane production rate to about $94 \%$ with a liquid recirculation rate equal to $0.63 \mathrm{~L} / \mathrm{h}$ (Luo et al., 2014a). 


\subsection{Optimum Conditions for production of methane}

A number of research studies have been conducted so far to optimize production of methane from anaerobic digestion. The findings are mainly based on lab-scale operation (Mao et al., 2015; Zhong et al., 2015). The final stage of methanogenesis in anaerobic digestion has been referred to have dependence on a number of process parameters such as temperature, $\mathrm{pH}$, hydraulic and solid retention time, organic loading rate, total ammonia nitrogen (TAN) etc. (Mao et al., 2015; Zhong et al., 2015). For a particular process variable, the optimum value is determined considering the remaining process parameters are fixed at optimum condition. Although an approach for tuning the process conditions simultaneously or dynamic modelling can provide more accurate result, a generic relationship can be established between methane production and change in temperature, $\mathrm{pH}$ retention time and OLR from literature review (Andre et al., 2016; Mao et al., 2015).

The following sub-section includes a simplified explanation about effects of temperature, $\mathrm{pH}$, retention time and organic loading rate in methane production. The additional treatment methods and additives for increased biogas production have been mentioned in the next section. Finally, the major challenges in implementing these concepts into industrial scale anaerobic digestion plant have been discussed.

\subsubsection{Temperature}

Temperature has a direct influence on the thermodynamic equilibrium of the biochemical reactions of anaerobic digestion and also controls the activities, growth rate and diversity of the microorganisms (Lin et al., 2016). During the production of methane, the microbial data in thermophilic and mesophilic system refers 
hydrogenotrophic and acetoclastic methanogenesis respectively. Therefore, the dominant pathway for methane production is defined by operating temperature of the digester (Zamanzadeh et al., 2016).

In thermophilic conditions $\left(55-70{ }^{\circ} \mathrm{C}\right)$, the growth rates for the methanogens are higher compared to the rate in mesophilic systems $\left(37^{\circ} \mathrm{C}\right.$ ) (Sun et al., 2015). The high rate of reaction enhances the system's load bearing capacity and the productivity of the thermophilic system compared to the mesophilic system. In contrast, the high reaction rate of acidogenesis in thermophilic process involves accumulation of propionic acid in the digester. It is not degraded due to the fact that propionate degradation requires five to six times lower hydrogen concentration compared to butyrate (Liu et al., 2012). The accumulated propionic acid then inhibits the activities by the methanogens. Results from an experiment show that when the propionic acid concentration reached above 1000 $\mathrm{mg} / \mathrm{L}$ as COD equivalent, it inhibited acetoclastic methanogenesis (Shofie et al., 2015). Furthermore, more energy input is required to maintain the system at a high temperature. Conversely, the mesophilic system offers a high yield of methane, better process stability, and greater richness in bacteria with less additional energy required for the system (Bowen et al., 2014).

Considering the facts mentioned above, a two-stage anaerobic process has been suggested including a thermophilic hydrolysis/acidogenesis and mesophilic methanogenesis process (Mao et al., 2015). Selecting the process operating temperature for methane production largely depends on the type and composition of the substrate. The hyperthermophilic $\left(70-80^{\circ} \mathrm{C}\right)$ anaerobic digestion process performs the best in treating the co-substrates as the decomposition of organic materials is easier at high 
temperature (Wang et al., 2014a; Wang et al., 2012). On this theme, a research study has been carried out to find out the optimum temperature for methane production from cattle and pig slurry (Elsgaard et al., 2016). Results here found that most methane was produced from stored digestate at $43-47{ }^{\circ} \mathrm{C}$. The results indicated a sharp increase in the production rate of methane in the 30 to $40{ }^{\circ} \mathrm{C}$ temperature range. This is because the mesophilic populations of methanogens were favored by the post-digestion storage system.

\subsection{2. $\mathrm{pH}$}

The $\mathrm{pH}$ of a reactor has a direct influence on the yield of methane production as the growth rate and activities of the microorganisms are greatly affected by the change in pH values (Yang et al., 2015). For single stage configuration, the optimum range has been reported to be 6.8-7.4 for methane production (Mao et al., 2015).

The narrow optimum range could be explained by the observation that the acidogenic and methanogenic activities reach their peak at $\mathrm{pH}$ range $5.5-6.5$ and 6.5-8.2 respectively (Mao et al., 2015). As rapid acidification by accumulation of propionic acid (mentioned before) easily reduces the $\mathrm{pH}$ of the digester below 6.5, maintaining $\mathrm{pH}$ in a single stage digester is particularly challenging during the production of methane (Fezzani \& Ben Cheikh, 2010; Mao et al., 2015). The alternative two-stage assembly for anaerobic digestion makes it possible to maximize the different stages of anaerobic digestion separately with optimum $\mathrm{pH}$ values for acidogens and methanogens. Intanoo et al. (2014) performed an experiment to produce biohydrogen and methane simultaneously from cassava wastewater using two-stage upflow anaerobic sludge blanket reactor (UASB). The $\mathrm{pH}$ of the initial hydrolysis stage was 
maintained at 5.5 while the $\mathrm{pH}$ of the second stage was not controlled. Instead, the experiment documented a low concentration of sodium hydroxide (230-350 mg/l) stimulating the activities of the methanogens in the second stage.

Furthermore, the production of ammonia can have a positive impact on resisting the sharp decrease of $\mathrm{pH}$ in a reactor. The experiment conducted by (Yang et al., 2015) revealed an increased yield of $\mathrm{CH}_{4}$ (7.57 times higher) when the $\mathrm{pH}$ was increased up to 8.0 compared to the conditions of $\mathrm{pH}$ uncontrolled group.

\subsubsection{Retention Time}

Both the hydraulic and solid retention time control the efficiency of biological methane production from the anaerobic digestion process (Mao et al., 2015). A low value of HRT involves the potential risk of biomass washout from the system, leading to a low methane yield. Results show that for the algal biomass an HRT less those 10 days decreases the methane productivity (Kwietniewska \& Tys, 2014).

Unlike the HRT, a low value of SRT favours methane production. Experiment on dewatered-sewage sludge in mesophilic and thermophilic conditions implied that biogas production trebled when the SRT was reduced from 30 to 12 days (Nges \& Liu, 2010). However, a SRT shorter than the optimum value can cause VFA accumulation, increased alkalinity and washout of the methanogens. In the same experiment a 9-day SRT created an imbalance in the process and resulted in the problem of foaming. In addition, Lee et al., (2011) mentioned an SRT from 2.5-4 day results in a complete washout of methanogens and the inhibition of methanogenesis.

To study the effect of hydraulic retention time, 24 full-scale biogas plants in Germany were studied for the digestion of cow manure and crops (Linke et al., 2013). From the 
experiment, the yield of methane was expressed as a function of HRT, proportion of crops in the input and the temperature. It was observed at temperatures less than $20^{\circ} \mathrm{C}$ digestate required a long time to reach the expected degradation (100 days for $H R T=60 \mathrm{~d})$ compared to the scenario where above $35^{\circ} \mathrm{C}$ degradation was very fast ( $<40$ days for $H R T=40 \mathrm{~d})$. As a consequence, the hydraulic retention time should be determined considering the operating temperature and the organic content of the substrate in a particular bioreactor.

\subsubsection{Organic loading rate}

Although the methane yield greatly depends on the percentage of the carbon component in the waste material, an organic loading rate exceeding the rate of decomposition or hydrolysis of the digester can actually cause a process imbalance and decline in methane production (Mao et al., 2015).

Quantification of VFA by High performance liquid chromatography (HPLC) (Zamanzadeh et al., 2016) or pH drop in digester could be utilized to find out the optimum loading rate (Aboudi et al., 2015; Farajzadehha et al., 2012). However, observing pH drop is more feasible for general applicability. A high organic loading rate leads to a high rate of initial acidogenesis that increases the amount of acid production. As mentioned previously, (i) the low rate of methanogenesis and (ii) accumulation of propionic acid acts to reduce the $\mathrm{pH}$ of a digester. Qiao et al., (2013) in this connection studied thermophilic co-digestion coffee ground in a submerged anaerobic membrane reactor. The results showed a high concentration of propionic acid $(1.0-3.2 \mathrm{~g} / \mathrm{L})$ consumed $60 \%$ of the total alkalinity when OLR was increased from 2.2 to $33.7 \mathrm{~kg}-\mathrm{COD} / \mathrm{m}^{3} \mathrm{~d}$. Table 3 lists the optimum values of OLR for different type of 
substrates and reactor configurations.

Table 3

From the table it is clear that the limitation in organic loading rate could be avoided in the two-stage anaerobic processes as it eliminates the possible inhibition of methanogenesis by acidification (Intanoo et al., 2014; Jariyaboon et al., 2015; Zhong et al., 2015). In this connection, a study aimed for simultaneous production of hydrogen and methane from palm oil mill effluent using two-stage thermophilic and mesophilic fermentation (Krishnan et al., 2016). The total hydrogen and methane yields were $215 \mathrm{~L}$ $\mathrm{H}_{2} / \mathrm{kgCOD}^{-1}$ and $320 \mathrm{~L} \mathrm{CH}_{4} / \mathrm{kgCOD}^{-1}$, respectively, with a concurrent removal of $94 \%$ organic content from the substrate.

\subsubsection{Other Parameters}

Different additives and physical and chemical pre-treatment methods have been applied to increase the biogas production. Results confirm that adding $\mathrm{Co}$ and $\mathrm{Ni}$ increases the amount of methane produced from anaerobic digestion and addition small amount of nanoparticles containing $\mathrm{Co}, \mathrm{Ni}, \mathrm{F}$ e and $\mathrm{Fe} 3 \mathrm{O} 4$ could increase biogas production up to 1.7 times (Abdelsalam et al., 2016).

A novel AD process was developed to produce pipeline quality bio-methane ( $>90 \%)$ from biochar-amended digesters through an enhanced $\mathrm{CO}_{2}$ removal process. The biochar-amended digesters achieved the removal of $\mathrm{CO}_{2}$ between $54.9-86.3 \%$ and the methane production rate rose to $27.6 \%$ (Shen et al., 2015). Anaerobic co-digestion of different substrates also improved the amount of methane created; pig manure with dewatered sewage sludge may increase methane production by $82 \%$ (Zhang et al., 
2014). Table 4 summarizes the effects of different types of additives/ treatment processes on increasing biogas production.

Table 4

\subsection{Challenges of methane production from industrial scale anaerobic digestion}

The previous discussion on optimization contains simple approach to maximize the production of methane in lab-scale operation. However, full-scale industrial operation involves a number challenges, such as:

- Although in general, high temperature favours production of methane for largescale industrial operation, ambient condition, type of waste and associated cost to maintain the temperature should be taken into account. For example, a research study on a $400 \mathrm{~m}^{3}$ BARC digester in Maryland (ambient temperature of $13{ }^{\circ} \mathrm{C}$ ) showed that the energy requirement decreased to $70 \%$ when the temperature was reduced from 35 to $28{ }^{\circ} \mathrm{C}$ (Arikan et al., 2015).

- There is always a trade-off between the high organic loading rate and cost associated to maintain the $\mathrm{pH}$ at optimum range $(6.5-8.2)$ for methanogens (Mao et al., 2015). The extraction of propionic acid can reduce the chance of rapid acidification in the digester. Results from research studies show that, removing propionic acid by solvent extraction can achieve an extraction yield of propionic acid up to $97 \%$ (Wang et al., 2009).

- Apart from optimizing one parameter at once; the optimization becomes more challenging when simultaneous changes in temperature, $\mathrm{pH}$, retention time and OLR are taken into account. The type and reactor configuration along with substrate composition defines the appropriate approach in this regard. 
- Table 3 clearly indicates a high organic loading could be applied to the digester with separate acidogenesis and methanogenesis stage. Implementing this idea in industrial scale involves the challenge of overcoming high capital (Membrane, tank, bioreactor) and operation (Fouling control, temperature and $\mathrm{pH}$ maintenance) costs (Khan et al., 2016; Pretel et al., 2015).

\section{Conclusion}

Research into VFA, biohydrogen and methane production from anaerobic digestion has advanced in recent times. However, the variable organic content in substrate still remains as the major drawback of this process against large-scale industrial application. Adapting the same anaerobic system for VFA, biohydrogen and methane individually or simultaneously could significantly improve the economic and environmental sustainability. Studies related to chemical additives, pre-treatment process and other process variables that were not considered here should be explored. A combination of treatment processes with optimized set of parameters could be beneficial to improve the production of $\mathrm{AD}$ products.

\section{References}

1. Abbasi, T., Abbasi, S.A. 2011. 'Renewable' hydrogen: Prospects and challenges. Renew. Sust. Energ. Rev. 15(6), 3034-3040.

2. Abdallah, R., Djelal, H., Amrane, A., Sayed, W., Fourcade, F., Labasque, T., Geneste, F., Taha, S., Floner, D. 2016. Dark fermentative hydrogen production by anaerobic sludge growing on glucose and ammonium resulting from nitrate electroreduction. Int. J. Hydrogen Energ. 41(12), 5445-5455.

3. Abdelsalam, E., Samer, M., Attia, Y.A., Abdel-Hadi, M.A., Hassan, H.E., Badr, Y. 2016. Comparison of nanoparticles effects on biogas and methane production from anaerobic digestion of cattle dung slurry. Renew. Energ. 87, 592-598.

4. Aboudi, K., Alvarez-Gallego, C.J., Romero-Garcia, L.I. 2015. Semi-continuous anaerobic co-digestion of sugar beet byproduct and pig manure: Effect of the organic loading rate (OLR) on process performance. Bioresour. Technol. 194, 28390. 
5. Adekunle, K.F., Okolie, J.A. 2015. A Review of Biochemical Process of Anaerobic Digestion. Adv. Biosci. Biotechnol. 06(03), 205-212.

6. Andre, L., Ndiaye, M., Pernier, M., Lespinard, O., Pauss, A., Lamy, E., Ribeiro, T. 2016. Methane production improvement by modulation of solid phase immersion in dry batch anaerobic digestion process: Dynamic of methanogen populations. Bioresour. Technol. 207, 353-60.

7. Angeriz-Campoy, R., Alvarez-Gallego, C.J., Romero-Garcia, L.I. 2015. Thermophilic anaerobic co-digestion of organic fraction of municipal solid waste (OFMSW) with food waste (FW): Enhancement of bio-hydrogen production. Bioresour. Technol. 194, 291-6.

8. Anzola-Rojas Mdel, P., Zaiat, M., De Wever, H. 2016. Improvement of hydrogen production via ethanol-type fermentation in an anaerobic down-flow structured bed reactor. Bioresour. Technol. 202, 42-9.

9. Arikan, O.A., Mulbry, W., Lansing, S. 2015. Effect of temperature on methane production from field-scale anaerobic digesters treating dairy manure. Waste Manag. 43, 108-13.

10. Arooj, M., Han, S., Kim, S., Kim, D., Shin, H. 2008. Continuous biohydrogen production in a CSTR using starch as a substrate. Int. J. Hydrogen Energ. 33(13), 3289-3294.

11. Bakonyi, P., Nemestóthy, N., Lankó, J., Rivera, I., Buitrón, G., Bélafi-Bakó, K. 2015. Simultaneous biohydrogen production and purification in a doublemembrane bioreactor system. Int. J. Hydrogen Energ. 40(4), 1690-1697.

12. Bakonyi, P., Nemestothy, N., Simon, V., Belafi-Bako, K. 2014. Fermentative hydrogen production in anaerobic membrane bioreactors: A review. Bioresour. Technol. 156, 357-63.

13. Bengtsson, S., Hallquist, J., Werker, A., Welander, T. 2008. Acidogenic fermentation of industrial wastewaters: Effects of chemostat retention time and $\mathrm{pH}$ on volatile fatty acids production. Biochem. Eng. J.40(3), 492-499.

14. Bohutskyi, P., Chow, S., Ketter, B., Betenbaugh, M.J., Bouwer, E.J. 2015. Prospects for methane production and nutrient recycling from lipid extracted residues and whole Nannochloropsis salina using anaerobic digestion. Appl. Energ. 154, 718-731.

15. Bowen, E.J., Dolfing, J., Davenport, R.J., Read, F.L., Curtis, T.P. 2014. Lowtemperature limitation of bioreactor sludge in anaerobic treatment of domestic wastewater. Water Sci. Technol. 69(5), 1004-13.

16. Cesaro, A., Belgiorno, V. 2013. Sonolysis and ozonation as pretreatment for anaerobic digestion of solid organic waste. Ultrason. Sonochem. 20(3), 931-6.

17. Cysneiros, D., Banks, C.J., Heaven, S., Karatzas, K.A. 2012. The effect of pH control and 'hydraulic flush' on hydrolysis and Volatile Fatty Acids (VFA) 
production and profile in anaerobic leach bed reactors digesting a high solids content substrate. Bioresour. Technol. 123, 263-71.

18. Davila-Vazquez, G., Cota-Navarro, C.B., Rosales-Colunga, L.M., de LeónRodríguez, A., Razo-Flores, E. 2009. Continuous biohydrogen production using cheese whey: Improving the hydrogen production rate. Int. J. Hydrogen Energ. 34(10), 4296-4304.

19. Eddy, M. 1991. Wastewater Engineering: Treatment, disposal and reuse. Third ed. Mc-Graw-Hill, Singapore.

20. Elsamadony, M., Tawfik, A., Suzuki, M. 2015. Surfactant-enhanced biohydrogen production from organic fraction of municipal solid waste (OFMSW) via dry anaerobic digestion. Appl. Energ. 149, 272-282.

21. Elsgaard, L., Olsen, A.B., Petersen, S.O. 2016. Temperature response of methane production in liquid manures and co-digestates. Sci. Total Environ.539, 78-84.

22. Farajzadehha, S., Mirbagheri, S.A., Farajzadehha, S., Shayegan, J. 2012. Lab Scale Study of HRT and OLR Optimization in UASB Reactor for Pretreating Fortified Wastewater in Various Operational Temperatures. APCBEE Procedia, 1, 90-95.

23. Fezzani, B., Ben Cheikh, R. 2010. Two-phase anaerobic co-digestion of olive mill wastes in semi-continuous digesters at mesophilic temperature. Bioresour. Technol. 101(6), 1628-34.

24. Grady, C.P.L., T., D.G., C., L.H. 2011. Biological Wastewater Treatment. Third Edition ed. CRC Press, Boca Raton.

25. Hafez, H., Nakhla, G., El. Naggar, M.H., Elbeshbishy, E., Baghchehsaraee, B. 2010. Effect of organic loading on a novel hydrogen bioreactor. Int. J. Hydrogen Energ. 35(1), 81-92.

26. Huang, Z., Ong, S.L., Ng, H.Y. 2013. Performance of submerged anaerobic membrane bioreactor at different SRTs for domestic wastewater treatment. J Biotechnol, 164(1), 82-90.

27. Intanoo, P., Chaimongkol, P., Chavadej, S. 2016. Hydrogen and methane production from cassava wastewater using two-stage upflow anaerobic sludge blanket reactors (UASB) with an emphasis on maximum hydrogen production. Int. J. Hydrogen Energ. 41(14), 6107-6114.

28. Intanoo, P., Rangsanvigit, P., Malakul, P., Chavadej, S. 2014. Optimization of separate hydrogen and methane production from cassava wastewater using twostage upflow anaerobic sludge blanket reactor (UASB) system under thermophilic operation. Bioresour. Technol. 173, 256-65.

29. Jariyaboon, R., S, O.T., Kongjan, P. 2015. Bio-hydrogen and bio-methane potentials of skim latex serum in batch thermophilic two-stage anaerobic digestion. Bioresour. Technol. 198, 198-206. 
30. Ji, Z., Chen, G., Chen, Y. 2010. Effects of waste activated sludge and surfactant addition on primary sludge hydrolysis and short-chain fatty acids accumulation. Bioresour. Technol. 101(10), 3457-62.

31. Jiang, J., Zhang, Y., Li, K., Wang, Q., Gong, C., Li, M. 2013. Volatile fatty acids production from food waste: effects of $\mathrm{pH}$, temperature, and organic loading rate. Bioresour. Technol. 143, 525-30.

32. Jiang, S., Chen, Y., Zhou, Q. 2007. Effect of sodium dodecyl sulfate on waste activated sludge hydrolysis and acidification. Chem. Eng. J. 132(1-3), 311-317.

33. Jie, W., Peng, Y., Ren, N., Li, B. 2014. Volatile fatty acids (VFAs) accumulation and microbial community structure of excess sludge (ES) at different pHs. Bioresour. Technol. 152, 124-9.

34. Jung, K.W., Kim, D.H., Shin, H.S. 2011. Fermentative hydrogen production from Laminaria japonica and optimization of thermal pretreatment conditions. Bioresour. Technol. 102(3), 2745-50.

35. Jurado, E., Antonopoulou, G., Lyberatos, G., Gavala, H.N., Skiadas, I.V. 2016. Continuous anaerobic digestion of swine manure: ADM1-based modelling and effect of addition of swine manure fibers pretreated with aqueous ammonia soaking. Appl. Energ. 172, 190-198.

36. Khan, M.A., Ngo, H.H., Guo, W.S., Liu, Y.W., Zhou, J.L., Zhang, J., Liang, S., Ni, B.J., Zhang, X.B., Wang, J. 2016. Comparing the value of bioproducts from different stages of anaerobic membrane bioreactors. Bioresour. Technol. 214, 81625.

37. Khatri, S., Wu, S., Kizito, S., Zhang, W., Li, J., Dong, R. 2015. Synergistic effect of alkaline pretreatment and $\mathrm{Fe}$ dosing on batch anaerobic digestion of maize straw. Appl. Energ. 158, 55-64.

38. Kim, T.H., Lee, Y., Chang, K.H., Hwang, S.J. 2012. Effects of initial lactic acid concentration, HRTs, and OLRs on bio-hydrogen production from lactate-type fermentation. Bioresour. Technol. 103(1), 136-41.

39. Kim, W., Shin, S.G., Lim, J., Hwang, S. 2013. Effect of temperature and hydraulic retention time on volatile fatty acid production based on bacterial community structure in anaerobic acidogenesis using swine wastewater. Bioproc. biosyst. Eng. 36(6), 791-8.

40. Krishnan, S., Singh, L., Sakinah, M., Thakur, S., Wahid, Z.A., Alkasrawi, M. 2016. Process enhancement of hydrogen and methane production from palm oil mill effluent using two-stage thermophilic and mesophilic fermentation. Int. J. Hydrogen Energ. 41(30), 12888-12898.

41. Kumar, G., Bakonyi, P., Periyasamy, S., Kim, S.H., Nemestóthy, N., Bélafi-Bakó, K. 2015. Lignocellulose biohydrogen: Practical challenges and recent progress. Renew. Sust. Energ. Rev. 44, 728-737. 
42. Kumar, G., Park, J.-H., Kim, M.-S., Kim, D.-H., Kim, S.-H. 2014. Hydrogen fermentation of different galactose-glucose compositions during various hydraulic retention times (HRTs). Int. J. Hydrogen Energ. 39(35), 20625-20631.

43. Kumar, G., Sivagurunathan, P., Park, J.H., Park, J.H., Park, H.D., Yoon, J.J., Kim, S.H. 2016. HRT dependent performance and bacterial community population of granular hydrogen-producing mixed cultures fed with galactose. Bioresour. Technol. 206, 188-94.

44. Kwietniewska, E., Tys, J. 2014. Process characteristics, inhibition factors and methane yields of anaerobic digestion process, with particular focus on microalgal biomass fermentation. Renew. Sust. Energ. Rev. 34, 491-500.

45. Lee, D., Li, Y., Oh, Y., Kim, M., Noike, T. 2009. Effect of iron concentration on continuous $\mathrm{H} 2$ production using membrane bioreactor. Int. J. Hydrogen Energ. 34(3), 1244-1252.

46. Lee, I.S., Parameswaran, P., Rittmann, B.E. 2011. Effects of solids retention time on methanogenesis in anaerobic digestion of thickened mixed sludge. Bioresour. Technol. 102(22), 10266-72.

47. Lee, J.Y., Chen, X.J., Lee, E.J., Min, K.S. 2012. Effects of pH and carbon sources on biohydrogen production by co-culture of Clostridium butyricum and Rhodobacter sphaeroides. J. Microbiol. Biotechn. 22(3), 400-6.

48. Lee, W.S., Chua, A.S.M., Yeoh, H.K., Ngoh, G.C. 2014. A review of the production and applications of waste-derived volatile fatty acids. Chem. Eng. J. 235, 83-99.

49. Lemmer, A., Chen, Y., Lindner, J., Wonneberger, A.M., Zielonka, S., Oechsner, H., Jungbluth, T. 2015. Influence of different substrates on the performance of a twostage high pressure anaerobic digestion system. Bioresour. Technol. 178, 313-8.

50. Lim, S.J., Kim, B.J., Jeong, C.M., Choi, J.D., Ahn, Y.H., Chang, H.N. 2008. Anaerobic organic acid production of food waste in once-a-day feeding and drawing-off bioreactor. Bioresour. Technol. 99(16), 7866-74.

51. Limwattanalert, N. 2011. Hydrogen production from ethanol wastewater by using upflow anaerobic sludge blanket reactor. in: The Petroleum and Petrochemical College, Vol. M.S, Chulalongkorn University.

52. Lin, Q., De Vrieze, J., He, G., Li, X., Li, J. 2016. Temperature regulates methane production through the function centralization of microbial community in anaerobic digestion. Bioresour. Technol. 216, 150-8.

53. Linke, B., Muha, I., Wittum, G., Plogsties, V. 2013. Mesophilic anaerobic codigestion of cow manure and biogas crops in full scale German biogas plants: a model for calculating the effect of hydraulic retention time and VS crop proportion in the mixture on methane yield from digester and from digestate storage at different temperatures. Bioresour. Technol. 130, 689-95. 
54. Liu, C.-M., Wu, S.-Y., Chu, C.-Y., Chou, Y.-P. 2014. Biohydrogen production from rice straw hydrolyzate in a continuously external circulating bioreactor. Int. J. Hydrogen Energ. 39(33), 19317-19322.

55. Liu, H., Wang, J., Liu, X., Fu, B., Chen, J., Yu, H.Q. 2012. Acidogenic fermentation of proteinaceous sewage sludge: Effect of pH. Water Res. 46(3), 799807.

56. Liu, I.C., Whang, L.-M., Ren, W.-J., Lin, P.-Y. 2011. The effect of pH on the production of biohydrogen by clostridia: Thermodynamic and metabolic considerations. Int. J. Hydrogen Energ. 36(1), 439-449.

57. Liu, Y., Zhang, Y., Quan, X., Li, Y., Zhao, Z., Meng, X., Chen, S. 2012. Optimization of anaerobic acidogenesis by adding $\mathrm{Fe} 0$ powder to enhance anaerobic wastewater treatment. Chem. Eng. J. 192, 179-185.

58. Luo, G., Wang, W., Angelidaki, I. 2014a. A new degassing membrane coupled upflow anaerobic sludge blanket (UASB) reactor to achieve in-situ biogas upgrading and recovery of dissolved $\mathrm{CH} 4$ from the anaerobic effluent. Appl. Energ. $132,536-542$.

59. Luo, G., Xie, L., Zou, Z., Wang, W., Zhou, Q., Shim, H. 2010. Anaerobic treatment of cassava stillage for hydrogen and methane production in continuously stirred tank reactor (CSTR) under high organic loading rate (OLR). Int. J. Hydrogen Energ. 35(21), 11733-11737.

60. Luo, J., Feng, L., Zhang, W., Li, X., Chen, H., Wang, D., Chen, Y. 2014b. Improved production of short-chain fatty acids from waste activated sludge driven by carbohydrate addition in continuous-flow reactors: Influence of SRT and temperature. Appl. Energ. 113, 51-58.

61. Luo, K., Yang, Q., Yu, J., Li, X.M., Yang, G.J., Xie, B.X., Yang, F., Zheng, W., Zeng, G.M. 2011. Combined effect of sodium dodecyl sulfate and enzyme on waste activated sludge hydrolysis and acidification. Bioresour. Technol. 102(14), 710310.

62. Mao, C., Feng, Y., Wang, X., Ren, G. 2015. Review on research achievements of biogas from anaerobic digestion. Renew. Sust. Energ. Rev. 45, 540-555.

63. Molinuevo-Salces, B., González-Fernández, C., Gómez, X., García-González, M.C., Morán, A. 2012. Vegetable processing wastes addition to improve swine manure anaerobic digestion: Evaluation in terms of methane yield and SEM characterization. Appl. Energ. 91(1), 36-42.

64. Monlau, F., Francavilla, M., Sambusiti, C., Antoniou, N., Solhy, A., Libutti, A., Zabaniotou, A., Barakat, A., Monteleone, M. 2016. Toward a functional integration of anaerobic digestion and pyrolysis for a sustainable resource management. Comparison between solid-digestate and its derived pyrochar as soil amendment. Appl. Energ. 169, 652-662. 
65. Nges, I.A., Liu, J. 2010. Effects of solid retention time on anaerobic digestion of dewatered-sewage sludge in mesophilic and thermophilic conditions. Renew. Energ. 35(10), 2200-2206.

66. Peces, M., Astals, S., Clarke, W.P., Jensen, P.D. 2016. Semi-aerobic fermentation as a novel pre-treatment to obtain VFA and increase methane yield from primary sludge. Bioresour. Technol. 200, 631-8.

67. Prajapati, S.K., Kaushik, P., Malik, A., Vijay, V.K. 2013. Phycoremediation coupled production of algal biomass, harvesting and anaerobic digestion: possibilities and challenges. Biotechnol. Adv. 31(8), 1408-25.

68. Pretel, R., Shoener, B.D., Ferrer, J., Guest, J.S. 2015. Navigating environmental, economic, and technological trade-offs in the design and operation of submerged anaerobic membrane bioreactors (AnMBRs). Water Res. 87, 531-41.

69. Qiao, W., Takayanagi, K., Niu, Q., Shofie, M., Li, Y.Y. 2013. Long-term stability of thermophilic co- digestion submerged anaerobic membrane reactor encountering high organic loading rate, persistent propionate and detectable hydrogen in biogas. Bioresour. Technol. 149, 92- 102.

70. Rincón, B., Borja, R., González, J.M., Portillo, M.C., Sáiz-Jiménez, C. 2008. Influence of organic loading rate and hydraulic retention time on the performance, stability and microbial communities of one-stage anaerobic digestion of two-phase olive mill solid residue. Biochem. Eng. J. 40(2), 253-261.

71. Rincon, B., Sanchez, E., Raposo, F., Borja, R., Travieso, L., Martin, M.A., Martin, A. 2008. Effect of the organic loading rate on the performance of anaerobic acidogenic fermentation of two-phase olive mill solid residue. Waste Manag. 28(5), 870-7.

72. Rittmann, S., Herwig, C. 2012. A comprehensive and quantitative review of dark fermentative biohydrogen production. Microb. Cell Fact. 11, 115.

73. Romero Aguilar, M.A., Fdez-Güelfo, L.A., Álvarez-Gallego, C.J., Romero García, L.I. 2013. Effect of HRT on hydrogen production and organic matter solubilization in acidogenic anaerobic digestion of OFMSW. Chem. Eng. J. 219, 443-449.

74. Ruggeri, B., Tommasi, T.S., Sara 2015. BioH2 \& BioCH4 Through Anaerobic Digestion. 2015 ed. Springer-Verlag London.

75. Scoma, A., Varela-Corredor, F., Bertin, L., Gostoli, C., Bandini, S. 2016. Recovery of VFAs from anaerobic digestion of dephenolized Olive Mill Wastewaters by Electrodialysis. Sep. Purif. Technol. 159, 81-91.

76. Shen, Y., Linville, J.L., Urgun-Demirtas, M., Schoene, R.P., Snyder, S.W. 2015. Producing pipeline-quality biomethane via anaerobic digestion of sludge amended with corn stover biochar with in-situ CO2 removal. Appl. Energ. 158, 300-309.

77. Shofie, M., Qiao, W., Li, Q., Takayanagi, K., Li, Y.-Y. 2015. Comprehensive monitoring and management of a long-term thermophilic CSTR treating coffee 
grounds, coffee liquid, milk waste, and municipal sludge. Bioresour. Technol. 192, 202-211.

78. Sun, W., Yu, G., Louie, T., Liu, T., Zhu, C., Xue, G., Gao, P. 2015. From mesophilic to thermophilic digestion: the transitions of anaerobic bacterial, archaeal, and fungal community structures in sludge and manure samples. Appl. Microbiol. Biot. 99(23), 10271-82.

79. Tang, J., Wang, X., Hu, Y., Zhang, Y., Li, Y. 2016. Lactic acid fermentation from food waste with indigenous microbiota: Effects of $\mathrm{pH}$, temperature and high OLR. Waste Manag. 52, 278-85.

80. Wang, K., Chang, Z., Ma, Y., Lei, C., Wang, J., Zhu, T., Liu, H., Zuo, Y., Li, X. 2009. Study on solvent extraction of propionic acid from simulated discharged water in vitamin B12 production by anaerobic fermentation. Bioresour. Technol. 100(11), 2878-2882.

81. Wang, F., Hidaka, T., Tsumori, J. 2014a. Enhancement of anaerobic digestion of shredded grass by co-digestion with sewage sludge and hyperthermophilic pretreatment. Bioresour. Technol. 169, 299-306.

82. Wang, F., Hidaka, T., Tsuno, H., Tsubota, J. 2012. Co-digestion of polylactide and kitchen garbage in hyperthermophilic and thermophilic continuous anaerobic process. Bioresour. Technol. 112, 67-74.

83. Wang, J., Wan, W. 2011. Combined effects of temperature and $\mathrm{pH}$ on biohydrogen production by anaerobic digested sludge. Biomass and Bioenerg. 35(9), 38963901 .

84. Wang, K., Yin, J., Shen, D., Li, N. 2014b. Anaerobic digestion of food waste for volatile fatty acids (VFAs) production with different types of inoculum: effect of pH. Bioresour. Technol. 161, 395-401.

85. Wang, Y., Zang, B., Li, G., Liu, Y. 2016. Evaluation the anaerobic hydrolysis acidification stage of kitchen waste by $\mathrm{pH}$ regulation. Waste Manag. 53, 62-7.

86. Wijekoon, K.C., Visvanathan, C., Abeynayaka, A. 2011. Effect of organic loading rate on VFA production, organic matter removal and microbial activity of a twostage thermophilic anaerobic membrane bioreactor. Bioresour. Technol. 102(9), 5353-60.

87. Wu, H., Gao, J., Yang, D., Zhou, Q., Liu, W. 2010. Alkaline fermentation of primary sludge for short-chain fatty acids accumulation and mechanism. Chem. Eng. J. 160(1), 1-7.

88. Wu, Y., Wang, C., Liu, X., Ma, H., Wu, J., Zuo, J., Wang, K. 2016. A new method of two-phase anaerobic digestion for fruit and vegetable waste treatment. Bioresour. Technol. 211, 16-23.

89. Yang, L., Huang, Y., Zhao, M., Huang, Z., Miao, H., Xu, Z., Ruan, W. 2015. Enhancing biogas generation performance from food wastes by high-solids 
thermophilic anaerobic digestion: Effect of $\mathrm{pH}$ adjustment. Int. Biodeter. Biodegr. 105, 153-159.

90. Yu, D., Liu, J., Sui, Q., Wei, Y. 2016a. Biogas-pH automation control strategy for optimizing organic loading rate of anaerobic membrane bioreactor treating high COD wastewater. Bioresour. Technol. 203, 62-70.

91. Yu, J., Zhao, Y., Liu, B., Zhao, Y., Wu, J., Yuan, X., Zhu, W., Cui, Z. 2016 b. Accelerated acidification by inoculation with a microbial consortia in a complex open environment. Bioresour. Technol. 216, 294-301.

92. Yu, J., Zheng, M., Tao, T., Zuo, J., Wang, K. 2013. Waste activated sludge treatment based on temperature staged and biologically phased anaerobic digestion system. J. Environ. Sci. 25(10), 2056-64.

93. Yuan, Q., Sparling, R., Oleszkiewicz, J.A. 2011. VFA generation from waste activated sludge: effect of temperature and mixing. Chemosphere. 82(4), 603-7.

94. Zamanzadeh, M., Hagen, L.H., Svensson, K., Linjordet, R., Horn, S.J. 2016. Anaerobic digestion of food waste - Effect of recirculation and temperature on performance and microbiology. Water Res. 96, 246-54.

95. Zhang, S., Lee, Y., Kim, T.H., Hwang, S.J. 2013. Effects of OLRs and HRTs on hydrogen production from high salinity substrate by halophilic hydrogen producing bacterium (HHPB). Bioresour. Technol. 141, 227-32.

96. Zhang, W., Wei, Q., Wu, S., Qi, D., Li, W., Zuo, Z., Dong, R. 2014. Batch anaerobic co-digestion of pig manure with dewatered sewage sludge under mesophilic conditions. Appl. Energ. 128, 175-183.

97. Zhang, Y., Chen, X., Gu, Y., Zhou, X. 2015. A physicochemical method for increasing methane production from rice straw: Extrusion combined with alkali pretreatment. Appl. Energ. 160, 39-48.

98. Zhong, J., Stevens, D.K., Hansen, C.L. 2015. Optimization of anaerobic hydrogen and methane production from dairy processing waste using a two-stage digestion in induced bed reactors (IBR). Int. J. Hydrogen Energ. 40(45), 15470-15476.

99. Zhuo, G., Yan, Y., Tan, X., Dai, X., Zhou, Q. 2012. Ultrasonic-pretreated waste activated sludge hydrolysis and volatile fatty acid accumulation under alkaline conditions: Effect of temperature. J. Biotechnol. 159(1-2), 27-31.

100.Zuo, Z., Wu, S., Qi, X., Dong, R. 2015. Performance enhancement of leaf vegetable waste in two- stage anaerobic systems under high organic loading rate: Role of recirculation and hydraulic retention time. Appl. Energ., 147, 279-286. 
Table 1: Effect of adding surfactants and/or enzymes on the production of VFA (Modified from (Lee et al., 2014))

\begin{tabular}{|c|c|c|c|c|c|}
\hline \multirow{2}{*}{ Additive(s) } & \multirow{2}{*}{ Waste } & \multirow{2}{*}{ Dosage } & \multicolumn{2}{|c|}{$\begin{array}{c}\text { Maximum VFA } \\
\text { Concentration }(\mathrm{mg} \mathrm{COD} / \mathrm{L})\end{array}$} & \multirow{2}{*}{ Reference } \\
\hline & & & $\begin{array}{c}\text { without } \\
\text { additives }\end{array}$ & $\begin{array}{c}\text { With } \\
\text { additives }\end{array}$ & \\
\hline $\begin{array}{c}\text { Sodium } \\
\text { dodecylben } \\
\text { zenesulfona } \\
\text { te (SDBS) }\end{array}$ & $\begin{array}{c}\text { Waste } \\
\text { activated } \\
\text { sludge + } \\
\text { primary } \\
\text { sludge }\end{array}$ & $0.02 \mathrm{~g} / \mathrm{g}$ TSS & $\begin{array}{c}118 \\
(\mathrm{mg} \mathrm{COD} / \mathrm{g} \mathrm{V} \\
\mathrm{SS})\end{array}$ & $\begin{array}{c}\text { 174(mg CO } \\
\mathrm{D} / \mathrm{g} \mathrm{VSS})\end{array}$ & $\begin{array}{l}\text { (Ji et al., } \\
\text { 2010) }\end{array}$ \\
\hline $\begin{array}{l}\text { Sodium } \\
\text { dodecyl } \\
\text { sulfate ( } \\
\text { SDS ) }\end{array}$ & $\begin{array}{c}\text { Waste } \\
\text { activated } \\
\text { sludge }\end{array}$ & $\begin{array}{l}0.1 \mathrm{~g} / \mathrm{g} \text { dry } \\
\quad \text { sludge }\end{array}$ & & 1143 & $\begin{array}{l}\text { (Jiang et } \\
\text { al., 2007) }\end{array}$ \\
\hline $\begin{array}{c}\alpha \text {-Amylase } \\
+ \text { neuter } \\
\text { protease }\end{array}$ & $\begin{array}{c}\text { Waste } \\
\text { activated } \\
\text { sludge }\end{array}$ & $\begin{array}{c}0.06 \mathrm{~g} / \mathrm{g} \text { dry } \\
\text { sludge }\end{array}$ & - & 1281 & $\begin{array}{l}\text { (Luo et al., } \\
\text { 2011) }\end{array}$ \\
\hline $\begin{array}{c}\text { SDS }+\alpha- \\
\text { amylase }+ \\
\text { neuter } \\
\text { protease }\end{array}$ & $\begin{array}{l}\text { Waste } \\
\text { activated } \\
\text { sludge }\end{array}$ & $\begin{array}{c}\mathrm{SDS}=0.1 \mathrm{~g} / \mathrm{g} \\
\text { dry sludge } \\
\text { Enzyme }=0.06 \\
\mathrm{~g} / \mathrm{g} \text { dry sludge }\end{array}$ & - & 1457 & $\begin{array}{l}\text { (Luo et al., } \\
\text { 2011) }\end{array}$ \\
\hline
\end{tabular}


Table 2. Results of maximum hydrogen production yield and optimal HRT and OLR (Modified from (Zhang et al., 2013))

\begin{tabular}{|c|c|c|c|c|c|}
\hline \multirow[b]{2}{*}{ Inoculum } & \multirow[b]{2}{*}{ Substrate } & \multicolumn{2}{|c|}{ Optimum Values } & \multirow{2}{*}{$\begin{array}{c}\text { Max. } H_{2} \\
\text { Yield }\end{array}$} & \multirow[b]{2}{*}{ Reference } \\
\hline & & HRT & ORL & & \\
\hline \multirow{3}{*}{$\begin{array}{c}\text { Anaerobic } \\
\text { digester } \\
\text { sludge }\end{array}$} & & & & 0.92 mol- & \\
\hline & & & $40 \mathrm{~g}-$ & $\mathrm{H}_{2} / \mathrm{mol}-$ & (Arooj et al., \\
\hline & Starch & $12 \mathrm{~h}$ & COD/L/day & glucose & \\
\hline \multirow{3}{*}{$\begin{array}{c}\text { Anaerobic } \\
\text { digester } \\
\text { sludge }\end{array}$} & & & $48 \mathrm{~g}-$ & 2.9 mol- & \\
\hline & & & glucose/L/d & $\mathrm{H}_{2} / \mathrm{mol}-$ & (Hafez et al., \\
\hline & Glucose & $8 \mathrm{~h}$ & ay & glucose & 2010) \\
\hline \multirow{2}{*}{$\begin{array}{l}\text { Anaerobic } \\
\text { granular } \\
\text { sludge }\end{array}$} & Cheese & & $\begin{array}{c}138.6 \mathrm{~g}- \\
\text { lactose/L/da }\end{array}$ & $\begin{array}{l}2.8 \mathrm{~mol}- \\
\mathrm{H}_{2} / \mathrm{mol}^{-}\end{array}$ & (Davila-Vazquez \\
\hline & whey & $6 \mathrm{~h}$ & $\mathrm{y}$ & lactose & et al., 2009) \\
\hline \multirow{2}{*}{$\begin{array}{l}\text { Anaerobic } \\
\text { sludge }\end{array}$} & & & $\begin{array}{c}40 \mathrm{~g}- \\
\text { glucose/L/d }\end{array}$ & $\begin{array}{l}1.2 \text { mol- } \\
\mathrm{H}_{2} / \mathrm{mol}-\end{array}$ & \\
\hline & Glucose & $12 \mathrm{~h}$ & ay & glucose & (Kim et al., 2012) \\
\hline \multirow{3}{*}{$\begin{array}{c}\text { Clostridium } \\
\text { bifermentan } \\
\text { s 3AT-ma }\end{array}$} & Glucose & & & & \\
\hline & (Containi & & $20 \mathrm{~g}-$ & $1.1 \mathrm{~mol}-$ & \\
\hline & $\begin{array}{c}\text { ng } 2 \% \text { of } \\
\mathrm{NaCl})\end{array}$ & $12 \mathrm{~h}$ & $\begin{array}{c}\text { glucose/L/d } \\
\text { ay }\end{array}$ & $\begin{array}{l}\mathrm{H}_{2} / \mathrm{mol}- \\
\text { glucose }\end{array}$ & $\begin{array}{c}\text { (Zhang et al., } \\
\text { 2013) }\end{array}$ \\
\hline
\end{tabular}


Table 3: Optimum OLR and $\mathrm{pH}$ range for methane production using different type of substrates

\begin{tabular}{|c|c|c|c|c|}
\hline Substrate & Reactor type & pH range & OLR & Reference \\
\hline $\begin{array}{l}\text { Sugar beet } \\
\text { cossettes, } \\
\text { pig manure }\end{array}$ & $\begin{array}{l}\text { Semi-continuous } \\
\text { stirred tank } \\
\text { reactor }\end{array}$ & $7.4-7.8$ & $11.2 \mathrm{gVS} / \mathrm{L}_{\text {reactor }} \mathrm{d}$ & $\begin{array}{l}\text { (Aboudi et } \\
\text { al., 2015) }\end{array}$ \\
\hline $\begin{array}{l}\text { High COD } \\
\text { wastewater }\end{array}$ & AnMBR & $>7.4$ & $\begin{array}{l}11.81 \mathrm{kgCOD} \cdot \mathrm{kgVSS}^{-1} \\
\cdot \mathrm{d}^{-1}\end{array}$ & $\begin{array}{l}\text { (Yu et al., } \\
\text { 2016a) }\end{array}$ \\
\hline $\begin{array}{l}\text { Dairy } \\
\text { waste }\end{array}$ & $\begin{array}{l}\text { Two stage } \\
\text { induced bed } \\
\text { reactor }\end{array}$ & $6.8-7.5$ & $32.9 \mathrm{~g}-\mathrm{COD} / \mathrm{l}-\mathrm{d}$ & $\begin{array}{l}\text { (Zhong et } \\
\text { al., 2015) }\end{array}$ \\
\hline $\begin{array}{l}\text { Olive mill } \\
\text { solid } \\
\text { residue }\end{array}$ & $\begin{array}{l}\text { Continuously } \\
\text { stirred tank } \\
\text { reactors }\end{array}$ & $7.3-7.5$ & $9.2 \mathrm{~g} \mathrm{COD} / \mathrm{L}$ day & $\begin{array}{l}\text { (Rincón et } \\
\text { al., 2008) }\end{array}$ \\
\hline $\begin{array}{l}\text { High- } \\
\text { strength } \\
\text { municipal } \\
\text { wastewater }\end{array}$ & $\begin{array}{l}\text { Upflow } \\
\text { anaerobic sludge } \\
\text { blanket reactor }\end{array}$ & $7.6-8.4$ & 7.2 to $10.8 \mathrm{~kg} \mathrm{~m}^{-3} \mathrm{~d}^{-1}$ & $\begin{array}{l}\text { (Farajzade } \\
\text { hha et al., } \\
\text { 2012) }\end{array}$ \\
\hline Food waste & $\begin{array}{l}\text { Thermophilic and } \\
\text { mesophilic } \\
\text { digester with } \\
\text { recirculation }\end{array}$ & $7.6-8.1$ & $18.5 \mathrm{gVS} / \mathrm{d}$ & $\begin{array}{l}\text { (Zamanzad } \\
\text { eh et al., } \\
2016)\end{array}$ \\
\hline $\begin{array}{l}\text { Olive mill } \\
\text { wastewater }\end{array}$ & $\begin{array}{l}\text { Two stage semi- } \\
\text { continuous } \\
\text { mesophilic } \\
\text { digesters }\end{array}$ & $\begin{array}{l}\text { 5.0-6.3 (For } \\
\text { acidogenesis) } \\
7.0-7.4 \text { (For } \\
\text { methanogenesis) }\end{array}$ & $\begin{array}{l}8.17 \pm 0.36 \mathrm{~g} \mathrm{COD} / \mathrm{L} / \mathrm{d} \\
\text { (acidogenesis) } \\
4.59 \pm 0.11 \mathrm{~g} \mathrm{COD} / \mathrm{L} / \mathrm{d} \\
\text { (Methanogenesis) }\end{array}$ & $\begin{array}{l}\text { (Fezzani \& } \\
\text { Ben } \\
\text { Cheikh, } \\
\text { 2010) }\end{array}$ \\
\hline $\begin{array}{l}\text { Vegetable } \\
\text { waste }\end{array}$ & $\begin{array}{l}\text { Completely } \\
\text { stirred tank } \\
\text { reactor } \\
\text { (Acidogenesis) } \\
\text { fixed-bed biofilm } \\
\text { (Methanogenesis) }\end{array}$ & $\begin{array}{l}5.1 \pm 0.1 \\
\text { (Acidogenic } \\
\text { reactor) } \\
7.6 \pm 0.1 \\
\text { (Methanogenic } \\
\text { reactor) }\end{array}$ & $3.0 \mathrm{~g} \mathrm{VS} / \mathrm{L} / \mathrm{d}$ & $\begin{array}{l}\text { (Zuo et al., } \\
\text { 2015) }\end{array}$ \\
\hline
\end{tabular}

Table 4: Additives/ treatment processes for increasing biogas production 


\begin{tabular}{|c|c|c|c|}
\hline Substrate & $\begin{array}{c}\text { Additives/ pre-treatment } \\
\text { process }\end{array}$ & Results & References \\
\hline Cattle dung slurry & $\begin{array}{c}1 \mathrm{mg} / \mathrm{L} \mathrm{Co}, 2 \mathrm{mg} / \mathrm{L} \mathrm{Ni}, \\
20 \mathrm{mg} / \mathrm{L} \mathrm{Fe} \text { and } 20 \mathrm{mg} / \mathrm{L} \\
\mathrm{Fe}_{3} \mathrm{O}_{4}\end{array}$ & $\begin{array}{l}\text { Biogas production up to } \\
1.7 \text { times }\end{array}$ & $\begin{array}{l}\text { (Abdelsala } \\
\text { m et al., } \\
\text { 2016) }\end{array}$ \\
\hline Rice straw & $\begin{array}{c}3 \% \mathrm{NaOH}\left(35^{\circ} \mathrm{C} \text { and for }\right. \\
48 \mathrm{~h})\end{array}$ & $\begin{array}{c}\text { Energy recovery increased } \\
\text { by } 59.9 \% \\
\end{array}$ & $\begin{array}{l}\text { (Zhang et } \\
\text { al., 2015) }\end{array}$ \\
\hline Maize straw & $\begin{array}{c}\mathrm{NaOH}(4 \% \text { and } 6 \%) \\
\text { pretreatment } \& \\
\text { Fe dosage }(50,200,1000 \\
\text { and } 2000 \mathrm{mg} / \mathrm{L})\end{array}$ & $\begin{array}{l}57 \% \text { and } 56 \% \text { higher } \\
\text { biogas and methane yield, } \\
\text { respectively }\end{array}$ & $\begin{array}{l}\text { (Khatri et } \\
\text { al., 2015) }\end{array}$ \\
\hline $\begin{array}{l}\text { Swine manure } \\
\text { fibers }\end{array}$ & $\begin{array}{l}\text { Aqueous ammonia soaking } \\
\text { (AAS) }\end{array}$ & $\begin{array}{l}98 \% \text { increase in the } \\
\text { methane yield }\end{array}$ & $\begin{array}{l}\text { (Jurado et } \\
\text { al., 2016) }\end{array}$ \\
\hline $\begin{array}{l}\text { Organic solid } \\
\text { waste }\end{array}$ & $\begin{array}{c}\text { Ozone dosage }(0.16 \mathrm{~g} \\
\left.\mathrm{O}_{3} / \mathrm{gTS}\right)\end{array}$ & $\begin{array}{l}37 \% \text { increase in biogas } \\
\text { volume }\end{array}$ & $\begin{array}{l}\text { (Cesaro \& } \\
\text { Belgiorno, } \\
\text { 2013) }\end{array}$ \\
\hline $\begin{array}{l}\text { a mixture of grass } \\
\text { and maize silage }\end{array}$ & High pressure (9 Bar) & $\begin{array}{l}77 \% \text { increase in methane } \\
\text { content in biogas }\end{array}$ & $\begin{array}{l}\text { (Lemmer et } \\
\text { al., 2015) }\end{array}$ \\
\hline Swine manure & $\begin{array}{c}\text { Vegetable wastes }(50 \% \\
\text { dw/dw) }\end{array}$ & $\begin{array}{l}\text { An improvement of 3- and } \\
1.4 \text {-fold in methane yield }\end{array}$ & $\begin{array}{l}\text { (Molinuevo } \\
\text {-Salces et } \\
\text { al., 2012) }\end{array}$ \\
\hline $\begin{array}{l}\text { Nannochloropsis } \\
\text { LEA, } \\
\text { Nannochloropsis } \\
\text { alga (WA) }\end{array}$ & $\begin{array}{l}\text { Thermal pre-treatment } \\
\qquad\left(150-170^{\circ} \mathrm{C}\right)\end{array}$ & $\begin{array}{c}40 \% \text { increase in methane } \\
\text { production (to } \\
0.31 \mathrm{~L} / \mathrm{gVS} \text { ) }\end{array}$ & $\begin{array}{l}\text { (Bohutskyi } \\
\text { et al., 2015) }\end{array}$ \\
\hline
\end{tabular}




\section{Highlights}

- Anaerobic digestion for production of VFAs, biohydrogen and methane.

- Specific bioreactor arrangements for VFAs, biohydrogen and methane.

- Optimization of temperature, $\mathrm{pH}$, OLR and retention time for each product.

- Chemical additives and specific treatment process for individual AD product. 

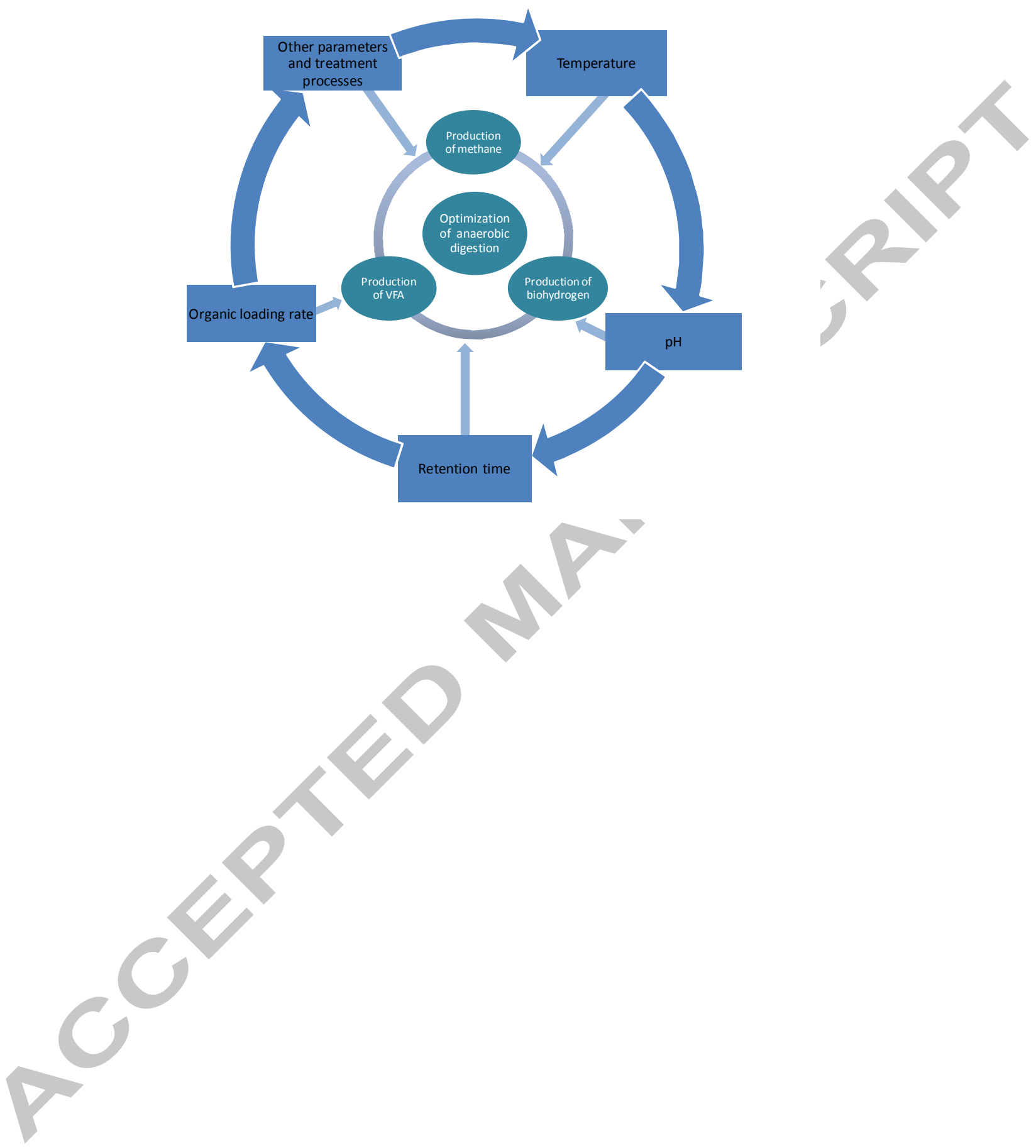